Borneo Journal of Sciences and Technology, Volume (1), Issue (2), Pages: 01-08

DOI: https://doi.org/10.35370/bjost.2019.1.2-01

e-ISSN: 2672-7439

(C) 2019, UCTS Publisher.

Submitted: $3^{\text {rd }}$ December 2018

Accepted: $15^{\text {th }}$ December 2018

Published: $31^{\text {st }}$ July 2019

\title{
Visible Light Driven Photocatalyst for Degradation of Organophosphate Pesticides: A Review
}

\author{
Poh Lin Lau, Augustine Chioma Affam \\ School of Engineering and Technology, University College of Technology Sarawak, 868, Brooke Drive, \\ 96000 Sibu, Sarawak,
}

\begin{abstract}
Organophosphates (OPs) are insecticide used to replace the persistence organochlorines (OCs). OPs are the effective insecticide used to control pests to enhance crops productions. Due to the strong recalcitrant properties, OPs cannot totally be degraded by conventional wastewater treatment process and the effluent causes negative impacts to the environment. The effectiveness of the AOPs is relied on the strong radical namely hydroxyl radicals $(\bullet \mathrm{OH})$ which can convert the pollutants into less harmful products. Photocatalysis is one of the AOPs widely practiced in water treatment process. A good photocatalyst must able to promote the electron from its valance band to the conduction band and the prevent the photogenerated electrons from returning to its valance band. The electron generated was further reacted with oxygen to form peroxyl radicals, $\bullet \mathrm{O}_{2}$. The hole $(\mathrm{h}+)$ formed was then react with water molecule to form $\bullet \mathrm{OH}$. Titanium dioxide, $\mathrm{TiO}_{2}$ is well known photocatalyst which only can be activated under ultra-violet light. Visible light photocatalysts are in the current research trend as they are found to be an effective method to degrade contaminants in wastewater. Various type of dopants has been doped on the $\mathrm{TiO}_{2}$ with different method purposely to shift the absorption of light from the UV light region to visible light region. The purpose of this review is to present the studies on different preparation method of the modified $\mathrm{TiO}_{2}$ and application of the modified $\mathrm{TiO}_{2}$ in degrading different types of OP pesticides. Finally, the need for present and further research on OPs wastewater also briefly discussed.
\end{abstract}

Keywords: Visible light photocatalysis, organophosphate, recalcitrant, pesticide wastewater, degradation

\section{INTRODUCTION}

Organophosphates (OP) are artificial pesticides found during the Second World War to replace the organochlorine pesticides [1] because they are not biodegradable by microorganisms as it is a strong class of carcinogenic water/wastewater contaminant [2]. Photocatalytic is well known as low cost, environmentally friendly and sustainable water treatment technology to remove different classes of the poisonous organic pollutants under various type light irradiator [3,4].

\subsection{Need for removal from environment}

Adverse effects of the pesticides that appeared in water and food have brought the great concern of scientific community [5]. Human health would be affected by the low concentration of pesticide residue (at $\mu \mathrm{g} / \mathrm{L}$ or $n g / L$ ) in the water such as neurodevelopment diseases, weakening of the immune system, cytotoxicity and mutagenicity. Besides that, endocrine system of mammals are also affected when the poisonous pesticides enter the body $[6,7,8,9]$.

\subsection{Conventional pesticide wastewater removal techniques}

Wastewater treatment method was first developed to deal to the adverse conditions caused by the discharge of wastewater to the environment and care for the public health [10]. From the early 1900 to 1970s, wastewater treatment focus on the BOD, suspended solids, pathogenic microorganism. After that, the objectives of the treatment expanded due to the awareness towards the water pollution and its long term effects to human health [10]. Several wastewater treatments, such as physical, chemical and biological process involving absorption, oxidation, catalytic degradation, membrane filtration and biological treatment have been performed $[10,11,12,13]$. Physical treatment does not completely mineralize the pollutants as it only transform them from one form to another form [15]. Meanwhile, chemical oxidation is costly and decontaminates the water with the toxic pollutants used [16]. Only a few specific fungal and

Corresponding Author: Poh Lin Lau. Affiliation: University College of Technology Sarawak, 868, Brooke Drive, 96000 Sibu,

Sarawak, email: plinlau20@yahoo.com 
bacteria were capable to be used as microbial degradation of pesticides [17] but the degradation process required a long period of time. Advantages and weakness of different water treatment are listed in Table 1 .

Table 1: Advantages and weakness of the wastewater treatments process

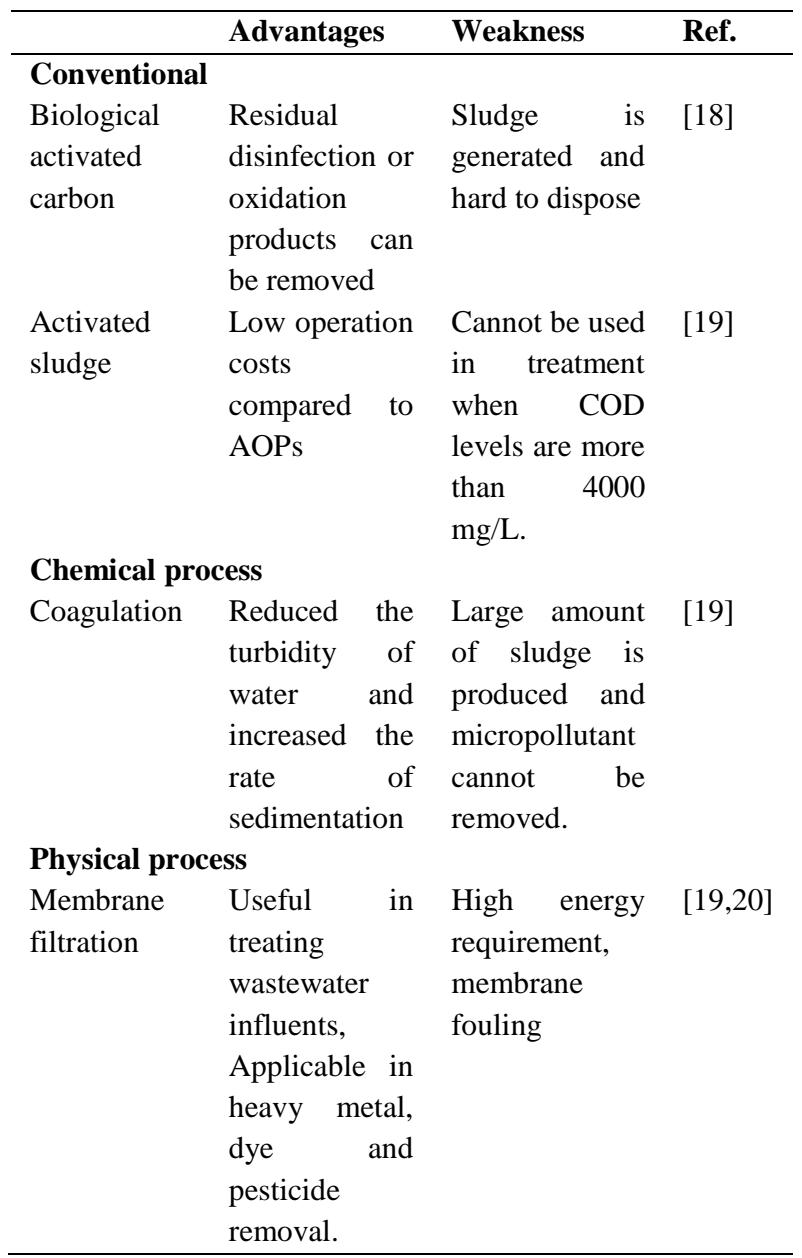

\subsection{Photocatalyst}

Photocatalyst, one of the advanced oxidation processes has been proven as an advanced and convenient way to mineralize toxic organics into harmless substances without the aids of extra chemicals in order to prevent the sludge production and its disposal [21]. Recently, many researchers have switched the studies from UV light-driven photocatalyst to visible light catalyst because there is only less than $5 \%$ of UV in the solar spectrum [22] while visible light occupied for $45 \%$ in the solar spectrum [23]. Thus, visible light driven photocatalysts can be used to degrade the organophosphates pesticides and more studies ought to be done in order to achieve greater results in degrading recalcitrant pesticides wastewater in Malaysia pesticides manufacturing industries in order to meet the effluent standard set up by Environmental Quality Act (EQA) 1974 as shown in Table 2. Therefore, more efforts should be done in this field in order to achieve efficient results which can be employed in industrial sectors. This mini review is written to address the common methods used to prepare modified $\mathrm{TiO}_{2}$ and the results of the certain OPs (methyl parathion, malathion and diazinon) removal using visible -light driven $\mathrm{TiO}_{2}$ photocatalyst.

Table 2: EQA regulation for discharge of treated wastewater

\begin{tabular}{|c|c|c|c|c|c|c|c|c|}
\hline \multirow[t]{4}{*}{ Parameter } & \multirow{2}{*}{\multicolumn{4}{|c|}{$\begin{array}{l}\text { Effluent Dischars } \\
\text { Rivers/ Stream }\end{array}$}} & \multirow{2}{*}{\multicolumn{4}{|c|}{$\begin{array}{l}\text { Effluent discharge } \\
\text { Stagnant Water Bodies }\end{array}$}} \\
\hline & & & & & & & & \\
\hline & \multicolumn{2}{|c|}{ Standard A } & \multicolumn{2}{|c|}{ Standard B } & \multicolumn{2}{|c|}{ Standard A } & \multicolumn{2}{|c|}{ Standard B } \\
\hline & \multicolumn{2}{|c|}{ Absolute } & \multicolumn{2}{|c|}{ Design } & \multicolumn{2}{|c|}{ Absolute } & \multicolumn{2}{|c|}{ Design } \\
\hline BOD & 20 & 10 & 50 & 20 & 20 & 10 & 50 & 20 \\
\hline SS & 50 & 20 & 100 & 40 & 50 & 20 & 100 & 40 \\
\hline COD & 120 & 60 & 200 & 100 & 120 & 60 & 200 & 100 \\
\hline $\mathrm{AMN}$ & 10 & 5 & 20 & 10 & 5 & 2 & 5 & 2 \\
\hline Nitrate & 20 & 10 & 50 & 20 & 10 & 5 & 10 & 5 \\
\hline \multicolumn{9}{|l|}{ Nitrogen } \\
\hline Total & N/A & N/A & N/A & N/A & 5 & 2 & 10 & 5 \\
\hline \multicolumn{9}{|l|}{ Phosphorus } \\
\hline O\&G & 5 & 2 & 10 & 5 & 5 & 2 & 10 & 5 \\
\hline
\end{tabular}

\section{1 $\mathrm{TiO}_{2}$}

Titanium is an inactive chemical element which is the ninth most common element found in the earth's crust. Its straightness is comparable with steel but its weighs $45 \%$ less then steel [24]. It appears as while solid with high thermal stability, inflammable, low solubility in water and strong anticorrosion [25]. $\mathrm{TiO}_{2}$ is made up of different rocks and minerals, thus, different types of $\mathrm{TiO} 2$ is formed such as rutile, anatase, brookie and Titanium dioxide (B) [25]. Differences in crystal structures and bandgaps of each type of titanium is shown in Table 3.

Table 3: Bandgap and crystal structure of different phase of $\mathrm{TiO}_{2}$

\begin{tabular}{lll}
\hline Phase & $\begin{array}{l}\text { Band Gap } \\
(\mathrm{eV})\end{array}$ & $\begin{array}{l}\text { Crystal } \\
\text { Structure }\end{array}$ \\
\hline Anatase & 3.2 & Tetragonal \\
Rutile & 3.0 & Tetragonal \\
\hline
\end{tabular}

\subsection{Preparation of modified $\mathrm{TiO}_{2}$}

The photodegradation performance of $\mathrm{TiO}_{2}$ is relied on following factors: (a) light absorption properties (b) the rata of separations of electrons and holes pairs and (c) the rate of recombination of electrons and holes [27]. 
Visible Light Driven Photocatalyst for Degradation of Organophosphate Pesticides: A Review

The wide band gap of $\mathrm{TiO}_{2}$ restricts its light absorption in visible light region [28]. $\mathrm{TiO}_{2}$ itself can be classified into different types such as Degussa P25, Millennium PC50, PC100, PC105, PC500 UV100 and TTIP (titanium tetraisopropoxide) [29]. Dopants poses excellent physiochemical properties such as formation of crystal with small size with high specific surface area [30]. Two types of dopants normally used, namely metals such as silver (Ag) [31], Palladium (Pd), Gold (Au) [32] and non - metals such as nitrogen (N) [33] and carbon (C) [34] There are 2 common methods to prepare the modified $\mathrm{TiO}_{2}$ namely (1) sol gel method (2) impregnation - precipitation-photoreduction.

\subsubsection{Sol-gel method}

Sol-gel has been practiced since mid-1800s. This method is used to prepare thin film and powder catalyst [35]. Tetrabutyl titanate $\left(\mathrm{Ti}(\mathrm{OBu})_{4}\right)$ [36] [37] and titanium tetraisopropoxide, TTIP [38] are two common $\mathrm{TiO}_{2}$ in liquid form used in sol-gel method. During the process, alcohol is added as the boiling point of alcohol controlled the particle size [39]. Acidifying agent is added to produce larger size of $\mathrm{TiO}_{2}$ [40] and study showed that hydrochloric acid (HCI) able to form anatase even the temperature was low [41]. High calcination temperature is required for this reaction (100 $-450{ }^{\circ} \mathrm{C}$ ) [42][38]. Although many reviews showed that sol-gel method can produce photocatalyst with high efficiency, the production cost is expensive as TTIP and $\left.\mathrm{Ti}(\mathrm{OBu})_{4}\right)$ are expensive than powdered $\mathrm{TiO}_{2}$. Meanwhile The high calcination temperature consumed massive amount of electricity. Besides, the dopants were normally doped by another method such as impregnation - precipitation - photoreduction. Table showed the $\mathrm{TiO}_{2}$ which are prepared by sol gel method and their application in water treatments.
Table 4: Sol sel method prepared photocatalyst and their application in wastewater treatments.

\begin{tabular}{|c|c|c|c|}
\hline Photocatalyst & $\begin{array}{l}\text { Contamin } \\
\text { ant }\end{array}$ & Results & Ref. \\
\hline${ }_{2} \mathrm{Ag} / \mathrm{AgBr} / \mathrm{TiO}$ & $\begin{array}{l}\text { Ibuprofen } \\
\text { and } E \text {. coli }\end{array}$ & $\begin{array}{l}\text { The sol gel } \\
\text { prepared } \\
\mathrm{TiO}_{2} \text { had } \\
\text { stronger } \\
\text { antibacterial } \\
\text { activities in } \\
\text { the dark } \\
\text { compared to } \\
\text { previous } \\
\text { reviews. }\end{array}$ & [38] \\
\hline $\begin{array}{l}\mathrm{TiO}_{2} / \text { fly ash } \\
\text { cenospheres } \\
\text { (FAC) }\end{array}$ & $\begin{array}{l}\text { rhodamine } \\
\mathrm{B}\end{array}$ & $\begin{array}{l}\mathrm{TiO}_{2} / \mathrm{FAC} \\
\text { could not } \\
\text { degrade } \\
\text { rhodamine } \mathrm{B} \\
\text { compared } \\
\text { with } \\
\mathrm{Ag} / \mathrm{AgBr} / \mathrm{Ti} \\
\mathrm{O}_{2} / \mathrm{FAC} \\
\text { prepared } \\
\text { with two- } \\
\text { step } \\
\text { approach. }\end{array}$ & [43] \\
\hline
\end{tabular}

\subsubsection{Impregnation - precipitation -photoreduction}

Impregnation defined as the fine distribution of chemicals and/or metal particles in the pore of certain reactants [44]. Some of the visible light-drivenphotocatalyst (metal /metal halide ) were prepared with this method $[41,42,43]$. Powdered $\mathrm{TiO}_{2}$ normally used in this process. During the process, powdered $\mathrm{TiO}_{2}$ was impregned with the dopants (in aqueous form) and stirred for certain time. The solution was then precipitated with metal halide and then irradiated with light before dried it in the oven. Meanwhile photoreduction is used to deposit the noble metal particles on a semiconductor using light irradiation [48]. This method is simple as the preparation time is shorter than other methods. In addition, High calcination temperature is not required for this process. Thus, it can be prepared easily in the laboratory.

\begin{tabular}{lll}
\hline Photocatalyst & Contaminant & Ref. \\
\hline $\mathrm{Ag} / \mathrm{AgCl} / \mathrm{TiO}_{2}$ & Dye (Methyl orange) & {$[49]$} \\
$\mathrm{Ag} / \mathrm{AgCl} / \mathrm{TiO}_{2}$ & Dye (Brilliant red) & {$[50]$} \\
\hline
\end{tabular}




\subsection{Organophosphate pesticide wastewater}

Wastewater containing organophosphate cannot totally removed by biological techniques [51]. The United States Environmental Protection Agency (USEPA) set up the wastewater constituents from pesticides manufacturing and formulation plants as summarized in Table 5. In Malaysia, very few studies have been done on the pesticide and the information is still lacking [52]. Based on the studies, pesticide residues had been detected in Perak, Selangor and Penang and also the sediments in Sabah and Sarawak [53].

Table 5: Summary of raw wastewater constituents

\begin{tabular}{lll}
\hline Pollutant group & $\begin{array}{l}\text { Design level } \\
(\mathbf{m g} / \mathbf{L})\end{array}$ & Ref. \\
\hline Volatile aromatics & $127-293,000$ & {$[54]$} \\
Halomethanes & $122-2600$ & \\
Cyanides & 5503 & \\
Phenols & $100-42,000$ & \\
Copper & 4500 & \\
Zinc & 247 & \\
Pesticides & $10-11,200$ & \\
BOD & $0-60,000$ & \\
COD & $14-1,220,000$ & \\
TTS & $2-4090$ \\
\hline
\end{tabular}

\subsection{Methyl parathion (O,O-Dimethyl-O-p- nitrophenyl- phosphorothioate)}

EPA has classified the methyl parathion (MP) as class I toxicity [55]. Overexposure to methyl parathion could lead to chronic diseases such as modulating reproductive, carcinogenic and immunosuppressive effects [56]. Methyl paraoxon, the main oxidation product of methyl parathion showed greater toxicological effect than its parent compound [57]. Visible light photocatalytic degradation of methyl parathion with various concentrations from $50 \mu \mathrm{g} / \mathrm{L}$ to $250 \mu \mathrm{g} / \mathrm{L}$ was conducted by mixing it with nitrogen (N) doped $\mathrm{TiO}_{2}$ from triethylamine precursor photocatalyst under $125 \mathrm{~W}$ visible tungsten halogen lamp that emits wavelengths ranging from 340 to $860 \mathrm{~nm}$. The result revealed that complete degradation of 50, 100 and 250 $\mu \mathrm{g} / \mathrm{L}$ of methyl parathion consumed 75,105 and $135 \mathrm{~min}$ for a suspended form of $\mathrm{N}$-doped $\mathrm{TiO}_{2}$ whereas 60,90 and $120 \mathrm{~min}$ was required for immobilized $\mathrm{N}$-doped $\mathrm{TiO}_{2}$ to degrade the same concentrations of methyl parathion [58]. Another experiment conducted where $\mathrm{Fe}_{3} \mathrm{O}_{4} @ \mathrm{SiO}_{2} @ \mathrm{TiO}_{2}$ able to totally remove $100 \mathrm{mg} / \mathrm{L}$ of MP under UV irradiation [59]. Compared with biological treatment method, an experiment was conducted where cyanobacterial strain was used to remove MP with the process known as biosorption where the cyanobacterial strain gained the phosphate from the MP. It consumed long time to incubate the cyanobacterial and the incubation was affected by the presence of light. The incubation of cyanobacterial only carried out in the light condition [60]. It is not suitable for huge MP manufacturing industries as the rate of bacterial incubation is lower than the rate of wastewater production. Visible- light driven photocatalyst shows its advantages as it can capture light whether it is UV light or visible light to start the photocatalytic activity.

\subsection{Diazinon (O,O-diethyl O-[6 methyl-2-(1- methylethyl)-4-pyrimidinyl] phosphorothioate}

Diazinon is classified as class II which is moderately hazardous by World Health Organization (WHO) [61]. Diazinon concentration in the range of $90-444 \mathrm{mg} / \mathrm{kg}$ leads human to die, thus it is important to remove the residues from the water[21]. Experiment has been done to study the absorption efficiency of activated carbon (AC) and $\mathrm{TiO}_{2} .0 .03 \mathrm{~g}$ of the $\mathrm{AC}$ and $\mathrm{TiO}_{2}$ were added separately with $40 \mathrm{mg} / \mathrm{L}$ diazinon and put in the dark for $80 \mathrm{~min}$. It was found the absorption efficiency of AC was better than $\mathrm{TiO}_{2}$. Another experiment was conducted to compare the photocatalytic of $\mathrm{AC}$ and $\mathrm{TiO}_{2}$. It was found that the diazinon removal by $\mathrm{AC}-\mathrm{TiO}_{2}$ composite was better than $\mathrm{TiO}_{2}$ alone under UV irradiation [21]. Another research conducted where xenon lamp with the wavelength in the range of $380-900 \mathrm{~nm}$ was used as light irradiator to degrade diazinon with different concentration. The result showed that $88 \%$ of $5.1 \mathrm{mg} / \mathrm{L}$ of diazinon was removed and mineralization percentage of $67.8 \%$ with $2.7 \mathrm{~g} / \mathrm{L}$ of nitrogen- doped $\mathrm{TiO}_{2}$ catalyst in $\mathrm{pH}$ medium of 5.9 while the removal efficiency was only $8 \%$ by photolysis and $18 \%$ by adsorption [62]. Degradation of $10 \mathrm{ppm}$ diazinon was carried out by 0.1 $\mathrm{Fe}_{2} \mathrm{O}_{3} / \mathrm{TiO}_{2}$ (metal dopant) The result showed the high removal as well [63]. It is found that absorption is a long-time consumption and low efficiency process. Expose to UV for long period can lead to skin cancer, visible light driven photocatalyst (produced with metal and non - metal dopant) can degrade diazinon as good as UV light. Table 6 showed the results for the absorption and visible light photocatalyst of diazinon wastewater. 
Visible Light Driven Photocatalyst for Degradation of Organophosphate Pesticides: A Review

Table 6: Different diazinon removal methods

\begin{tabular}{|c|c|c|c|c|}
\hline Method & $\begin{array}{l}\text { Initial } \\
\text { concentr } \\
\text { ation }\end{array}$ & $\begin{array}{l}\text { Remov } \\
\text { al }(\%)\end{array}$ & $\begin{array}{l}\begin{array}{l}\text { Time } \\
\text { take } \\
(\text { min) }\end{array} \\
\end{array}$ & Ref. \\
\hline \multicolumn{5}{|c|}{ Absorption } \\
\hline $\mathrm{AC}$ & $40 \mathrm{mg} / \mathrm{L}$ & 35 & 80 & [21] \\
\hline $\mathrm{TiO}_{2}$ & $40 \mathrm{mg} / \mathrm{L}$ & 15 & 80 & \\
\hline \multicolumn{5}{|c|}{ Visible light photocatalysis } \\
\hline $\begin{array}{l}\mathrm{TiO}_{2} / \mathrm{Fe}_{2} \\
\mathrm{O}_{3} \\
\text { nanocom } \\
\text { posite }\end{array}$ & $10 \mathrm{ppm}$ & 89.21 & 45 & [63] \\
\hline $\begin{array}{l}\mathrm{N} \text { - doped } \\
\mathrm{TiO}_{2}\end{array}$ & $5.1 \mathrm{mg} / \mathrm{L}$ & 88 & 88 & [62] \\
\hline
\end{tabular}

\subsection{Malathion (S-1,2-bis(ethoxicarbonyl)ethyl 0,0- dimethyl-phosphorodithioate)}

Malathion is water soluble pesticides that could endanger to wildlife and public health [64]. Since it has high toxicity, the US EPA restricted the presentation of malathion in drinking water should not be higher than $0.1-0.2 \mathrm{mg} / \mathrm{L}$, thus its amount should be controlled in the water resources [65]. $\mathrm{Au}-\mathrm{Pd}-\mathrm{TiO}_{2}$ visible light generated photocatalyst was used to study the photodegradation of malathion under irradiation of 450W high-pressure mercury lamp which emits the wavelength at $365 \mathrm{~nm}$. The degradation rate yielded 98.2 $\%$ in 2 hours which is higher than bare $\mathrm{TiO}_{2}$ which removed $73.8 \%$ of malathion [66]. $1 \mathrm{~g} / \mathrm{dm}^{3}$ of $\mathrm{N}$-doped $\mathrm{TiO}_{2}$ photocatalyst was applied to degrade $100 \mathrm{~mL}$ of 15 ppm malathion and it was discovered that $97 \%$ of malathion degraded within 150 minutes in $\mathrm{pH}$ medium of 6 under UV light with the wavelength of $364 \mathrm{~nm}$ which is fall in the visible light region. Meanwhile, the carbon oxygen demand (COD) was deduced from 50 to $10 \mathrm{mg}$ implied that $80 \%$ mineralization of the malathion [27]. The degradation of $12 \mathrm{mg} / \mathrm{L}$ of malathion with 1 $\mathrm{g} / \mathrm{L}$ of $2 \% \mathrm{WO}_{3} / \mathrm{TiO}_{2}$ in $\mathrm{pH}$ medium of 7 and the result stated that degradation was completed in $120 \mathrm{~min}$ and $63 \%$ of the pesticide was mineralized after 300 minutes. Even though the experiments were carried out under natural solar irradiation, photocatalytic process absorbed visible light to start the reaction [68]. Hereby it can be justified that the presence of metals and non - metals dopant showed their ability to degrade the malathion without the chemical or materials that are required in other wastewater treatment process as shown in Table 7.
Table 7: Different malathion removal methods

\begin{tabular}{|c|c|c|}
\hline $\begin{array}{l}\text { Chemicals / Material } \\
\text { required }\end{array}$ & Disadvantage & Ref. \\
\hline \multicolumn{3}{|l|}{ Nanofiltration } \\
\hline $\begin{array}{ll}\text { - } & \text { Membrane filter } \\
\text { - } & \text { High pressure }\end{array}$ & $\begin{array}{l}\text { High energy } \\
\text { consumption }\end{array}$ & \\
\hline & $\begin{array}{l}\text { Appropriate } \\
\text { pore size and } \\
\text { material must be } \\
\text { known to } \\
\text { produce a good } \\
\text { membrane }\end{array}$ & [69] \\
\hline $\begin{aligned} & \text { Photo-Fenton reaction } \\
& \text { - } \text { Hydrogen } \\
& \text { peroxide }\left(\mathrm{H}_{2} \mathrm{O}_{2}\right) \\
& \text { - } \text { ferrous sulfate } \\
& \text { heptahydrate } \\
&\left(\mathrm{FeSO} \mathrm{S}_{4} \cdot 7 \mathrm{H}_{2} \mathrm{O}\right)\end{aligned}$ & $\begin{array}{l}\mathrm{H}_{2} \mathrm{O}_{2} \text { is needed } \\
\text { to promote its } \\
\text { effectiveness }\end{array}$ & \\
\hline
\end{tabular}

\section{CONCLUSION}

Photocatalysts have been proven as low cost and environmentally friendly technology in wastewater remediation process. However, most of the photocatalysts only can be activated by UV light. Although visible light driven photocatalysts have been used in degradation of organic pollutants such as dye water, pharmaceutical products and pathogenic microorganics, information on degradation of organophosphate pesticides by the visible light photocatalyst is still lacking. Some of the intermediates formed (oxons) during photolysis were more toxic compared to parent compounds. However, not many researches have conducted on the degradation of the byproducts. Thus, monitoring the toxicity during the degradation is essential to ensure safer handling of pesticide wastewater. Form the review, we can conclude that visible light driven photocatalysts are able to accelerate the mineralization and degradation of the organophosphate pesticide was accomplished by the modified $\mathrm{TiO}_{2}$. From the review, points on the future scope were summarized:

1. More study is needed to discover various types of visible light driven catalyst for degradation of OPs.

2. Rebuilt the new tech wastewater treatment process can is burdening. We can combine the current biological treatment with photocatalysis in pre and post wastewater treatment. Thus, the sludge formation can be reduced and enhance the quality of water effluent in order to meet the EQA standard. 
3 Most of the photodegradation of the pesticide experiments conducted in lab scale can be improved hence applicable in pesticide manufacturing industries.

\section{REFERENCES}

[1] I.A. Shabtai, Y.G. Mishael, Catalytic polymerclay composite for enhanced removal and degradation of diazinon, J. Hazard. Mater. 335 (2017) 135-142.

[2] P. Kabwadza-Corner, M.W. Munthali, E. Johan, N. Matsue, Comparative Study of Copper Adsorptivity and Selectivity toward Zeolites, Am. J. Anal. Chem. 5 (2014) 395.

[3] I.K. Konstantinou, T.A. Albanis, Photocatalytic transformation of pesticides in aqueous titanium dioxide suspensions using artificial and solar light: intermediates and degradation pathways, Appl. Catal. B Environ. 42 (2003) 319-335.

[4] S. Gomez, C.L. Marchena, L. Pizzio, L. Pierella, Preparation and characterization of TiO2/HZSM-11 zeolite for photodegradation of dichlorvos in aqueous solution, J. Hazard. Mater. 258 (2013) 19-26.

[5] P. Cabras, A. Angioni, Pesticide residues in grapes, wine, and their processing products, $\mathrm{J}$. Agric. Food Chem. 48 (2000) 967-973.

[6] H.S. Rathore, L.M.L. Nollet, Pesticides: Evaluation of environmental pollution, 2012.

[7] M. Čolović, D. Krstić, S. Petrović, A. Leskovac, G. Joksić, J. Savić, M. Franko, P. Trebše, V. Vasić, Toxic effects of diazinon and its photodegradation products, Toxicol. Lett. 193 (2010) 9-18.

[8] M. Jafari, M. Salehi, S. Ahmadi, A. Asgari, M. Abasnezhad, M. Hajigholamali, The role of oxidative stress in diazinon-induced tissues toxicity in Wistar and Norway rats, Toxicol. Mech. Methods. 22 (2012) 638-647.

[9] M. Cycoń, A. Zmijowska, M. Wójcik, Z. Piotrowska-Seget, Biodegradation and bioremediation potential of diazinon-degrading Serratia marcescens to remove other organophosphorus pesticides from soils, J. Environ. Manage. 117 (2013) 7-16.

[10] P. Rajasulochana, V. Preethy, Comparison on efficiency of various techniques in treatment of waste and sewage water - A comprehensive review, Resour. Technol. 2 (2016) 175-184.

[11] F.B. Li, X.M. Li, S.G. Zhou, L. Zhuang, F. Cao, D.Y. Huang, W. Xu, T.X. Liu, C.H. Feng, Enhanced reductive dechlorination of DDT in an anaerobic system of dissimilatory iron-reducing bacteria and iron oxide, Environ. Pollut. 158 (2010) 1733-1740.
[12] P.C.H. Li, E.J. Swanson, F.A.P.C. Gobas, Photocatalytic oxidation of toxic organohalides with $\mathrm{TiO} 2 / \mathrm{UV}$ : the effects of humic substances and organic mixtures, Bull. Environ. Contam. Toxicol. 69 (2002) 1872-1877.

[13] E. Smith, J. Smith, R. Naidu, A.L. Juhasz, Desorption of DDT from a contaminated soil using cosolvent and surfactant washing in batch experiments, Water. Air. Soil Pollut. 151 (2004) 71-86.

[14] S.S. Zinovyev, N.A. Shinkova, A. Perosa, P. Tundo, Liquid phase hydrodechlorination of dieldrin and DDT over $\mathrm{Pd} / \mathrm{C}$ and Raney-Ni, Appl. Catal. B Environ. 55 (2005) 39-48.

[15] R. Saini, P. Kumar, Optimization of chlorpyrifos degradation by Fenton oxidation using CCD and ANFIS computing technique, J. Environ. Chem. Eng. 4 (2016) 2952-2963..

[16] E. Moctezuma, E. Leyva, G. Palestino, H. de Lasa, Photocatalytic degradation of methyl parathion: Reaction pathways and intermediate reaction products, J. Photochem. Photobiol. A Chem. 186 (2007) 71-84.

[17] Z. Chishti, S. Hussain, K.R. Arshad, A. Khalid, M. Arshad, Microbial degradation of chlorpyrifos in liquid media and soil, J. Environ. Manage. 114 (2013) 372-380.

[18] J. Radjenović, M. Matošić, I. Mijatović, M. Petrović, D. Barceló, Membrane bioreactor (MBR) as an advanced wastewater treatment technology, Emerg. Contam. from Ind. Munic. Waste. (2007) 37-101.

[19] Y. Luo, W. Guo, H.H. Ngo, L.D. Nghiem, F.I. Hai, J. Zhang, S. Liang, X.C. Wang, A review on the occurrence of micropollutants in the aquatic environment and their fate and removal during wastewater treatment, Sci. Total Environ. 473, (2014) 619-641.

[20] S.A. Snyder, S. Adham, A.M. Redding, F.S. Cannon, J. DeCarolis, J. Oppenheimer, E.C. Wert, Y. Yoon, Role of membranes and activated carbon in the removal of endocrine disruptors and pharmaceuticals, Desalination. 202 (2007) 156-181.

[21] A.F. Hassan, H. Elhadidy, A.M. Abdel-Mohsen, Adsorption and photocatalytic detoxification of diazinon using iron and nanotitania modified activated carbons, J. Taiwan Inst. Chem. Eng. 75 (2017) 299-306.

[22] C.M. Teh, A.R. Mohamed, Roles of titanium dioxide and ion-doped titanium dioxide on photocatalytic degradation of organic pollutants (phenolic compounds and dyes) in aqueous solutions: A review, J. Alloys Compd. 509 (2011) 1648-1660. 
Visible Light Driven Photocatalyst for Degradation of Organophosphate Pesticides: A Review

[23] C.K. Cheng, M. Rizauddin Derahman, M.R. Khan, Evaluation of the photocatalytic degradation of pre-treated palm oil mill effluent (POME) over Pt-loaded titania, J. Environ. Chem. Eng. 3 (2015) 261-270.

[24] L. Woodruff, G.M. Bedinger, Titanium - Light, Strong, and White, 2013.

[25] N. Abdullah, S.K. Kamarudin, Titanium dioxide in fuel cell technology: An overview, J. Power Sources. 278 (2015) 109-118.

[26] D. Reyes-Coronado, G. Rodriguez-Gattorno, M.E. Espinosa-Pesqueira, C. Cab, R. De Coss, G. Oskam, Phase-pure TiO2 nanoparticles: Anatase, brookite and rutile, Nanotechnology. (2008).

[27] H. Kominami, S.Y. Murakami, J.I. Kato, Y. Kera, B. Ohtani, Correlation between some physical properties of titanium dioxide particles and their photocatalytic activity for some probe reactions in aqueous systems, J. Phys. Chem. B. 106 (2002) 10501-10507.

[28] R. Jaiswal, N. Patel, D.C. Kothari, A. Miotello, Improved visible light photocatalytic activity of TiO 2 co-doped with Vanadium and Nitrogen, Appl. Catal. B Environ. 126 (2012) 47-54.

[29] M.H. Alhaji, K. Sanaullah, S.F. Lim, A. Khan, C.N. Hipolito, M.O. Abdullah, S.A. Bhawani, T. Jamil, Photocatalytic treatment technology for palm oil mill effluent (POME) - A review, Process Saf. Environ. Prot. 102 (2016) 673-686.

[30] P. Pongwan, K. Wetchakun, S. Phanichphant, N. Wetchakun, Enhancement of visible-light photocatalytic activity of $\mathrm{Cu}$-doped $\mathrm{TiO} 2$ nanoparticles, Res. Chem. Intermed. 42 (2016) 2815-2830.

[31] H. Yin, X. Wang, L. Wang, Q. Nie, Y. Zhang, Q. Yuan, W. Wu, Ag/AgCl modified self-doped $\mathrm{TiO} 2$ hollow sphere with enhanced visible light photocatalytic activity, J. Alloys Compd. 657 (2016) 44-52.

[32] M.M. Khan, J. Lee, M.H. Cho, Au@TiO2 nanocomposites for the catalytic degradation of methyl orange and methylene blue: An electron relay effect, J. Ind. Eng. Chem. 20 (2014) 15841590. [33] C. Shifu, C. Lei, G. Shen, C. Gengyu, The preparation of nitrogen-doped photocatalyst $\mathrm{TiO} 2-\mathrm{xNx}$ by ball milling, Chem. Phys. Lett. 413 (2005) 404-409.

[34] T. Jiang, L. Zhang, M. Ji, Q. Wang, Q. Zhao, X. $\mathrm{Fu}, \mathrm{H}$. Yin, Carbon nanotubes/TiO2 nanotubes composite photocatalysts for efficient degradation of methyl orange dye, Particuology. 11 (2013) 737-742.

[35] U.G. Akpan, B.H. Hameed, The advancements in sol-gel method of doped-TiO2 photocatalysts,
Appl. Catal. A Gen. 375 (2010) 1-11.

[36] D. Wang, Y. Duan, Q. Luo, X. Li, J. An, L. Bao, L. Shi, Novel preparation method for a new visible light photocatalyst: mesoporous $\mathrm{TiO} 2$ supported Ag/AgBr, J. Mater. Chem. 22 (2012) 4847.

[37] M. Pohl, H. Kurig, I. Tallo, A. Jänes, E. Lust, Novel sol-gel synthesis route of carbide-derived carbon composites for very high power density supercapacitors, Chem. Eng. J. 320 (2017) 576587

[38] X. Wang, Y. Tang, Z. Chen, T.-T. Lim, Highly stable heterostructured $\mathrm{Ag}-\mathrm{AgBr} / \mathrm{TiO} 2$ composite: a bifunctional visible-light active photocatalyst for destruction of ibuprofen and bacteria, J. Mater. Chem. 22 (2012) 23149.

[39] Y.C. Wu, Y.C. Tai, Effects of alcohol solvents on anatase $\mathrm{TiO} 2$ nanocrystals prepared by microwave-assisted solvothermal method, J. Nanoparticle Res. 15 (2013) 1686.

[40] N. Behnajady, M.A., Eskandarloo, H., Modirshahla, M. Shokri, Sol-Gel Lowtemperature Synthesis of Stable Anatase-type $\mathrm{TiO} 2$ Nanoparticles Under Different Conditions and its Photocatalytic Activity, Photochem. Photobiol. 87 (2011) 1002-1008.

[41] J. Livage, M. Henry, C. Sanchez, Sol-gel chemistry of transition metal oxides, Prog. Solid State Chem. 18 (1988) 259-341.

[42] A.C. Martins, A.L. Cazetta, O. Pezoti, J.R.B. Souza, T. Zhang, E.J. Pilau, T. Asefa, V.C. Almeida, Sol-gel synthesis of new TiO2/activated carbon photocatalyst and its application for degradation of tetracycline, Ceram. Int. 43 (2017) 4411-4418.

[43] S. Liu, J. Zhu, Q. Yang, P. Xu, J. Ge, X. Guo, Synthesis and characterization of cube-like $\mathrm{Ag} @ \mathrm{AgCl}$-doped $\mathrm{TiO} 2 / \mathrm{fly}$ ash cenospheres with enhanced visible-light photocatalytic activity, Opt. Mater. (Amst). 53 (2016) 73-79.

[44] A. Bhatnagar, W. Hogland, M. Marques, M. Sillanpää, An overview of the modification methods of activated carbon for its water treatment applications, Chem. Eng. J. 219 (2013) 499-511.

[45] J. Zhou, Y. Cheng, J. Yu, Preparation and characterization of visible-light-driven plasmonic photocatalyst $\mathrm{Ag} / \mathrm{AgCl} / \mathrm{TiO} 2$ nanocomposite thin films, J. Photochem. Photobiol. A Chem. 223 (2011) 82-87.

[46] J. Gamage McEvoy, W. Cui, Z. Zhang, Synthesis and characterization of $\mathrm{Ag} / \mathrm{AgCl}-$ activated carbon composites for enhanced visible light photocatalysis, Appl. Catal. B Environ. 144 (2014) 702-712. 
Visible Light Driven Photocatalyst for Degradation of Organophosphate Pesticides: A Review

[47] J. Gamage McEvoy, Z. Zhang, Synthesis and characterization of $\mathrm{Ag} / \mathrm{AgBr}$-activated carbon composites for visible light induced photocatalytic detoxification and disinfection, $\mathrm{J}$. Photochem. Photobiol. A Chem. 321 (2016) 161-170.

[48] N.P. Radhika, R. Selvin, R. Kakkar, A. Umar, Recent advances in nano-photocatalysts for organic synthesis, Arab. J. Chem. (2016).

[49] J. Yu, G. Dai, B. Huang, Fabrication and characterization of visible-light-driven plasmonic photocatalyst $\mathrm{Ag} / \mathrm{AgCl} / \mathrm{TiO} 2$ nanotube arrays, J. Phys. Chem. C. 113 (2009)

[50] N. Bao, X. Miao, X. Hu, Q. Zhang, X. Jie, X. Zheng, Novel synthesis of plasmonic $\mathrm{Ag} / \mathrm{AgCl} @ \mathrm{TiO}$ continues fibers with enhanced broadband photocatalytic performance, Catalysts. 7 (2017) 117.

[51] M. Hincapié, M.I. Maldonado, I. Oller, W. Gernjak, J.A. Sánchez-Pérez, M.M. Ballesteros, S. Malato, Solar photocatalytic degradation and detoxification of EU priority substances, Catal. Today. 101 (2005) 203-210.

[52] K.H. Leong, L.L. Benjamin Tan, A.M. Mustafa, Contamination levels of selected organochlorine and organophosphate pesticides in the Selangor River, Malaysia between 2002 and 2003, Chemosphere. 66 (2007) 1153-1159.

[53] A.R. Abdullah, Environmental pollution in Malaysia: trends and prospects, Trends Anal. Chem. 14 (1995) 191-198.

[54] U.S. EPA, Development document for effluent limitations guidelines and standards for the pulp, paper, and paperboard and the builders paper and board mills, 1980.

[55] D. Sud, P. Kaur, Heterogeneous photocatalytic degradation of selected organophosphate pesticides: A review, Crit. Rev. Environ. Sci. Technol. 42 (2012) 2365-2407.

[56] M.N.U. Coral, S. Ucman, Y. Hasan, O. Haydar, D. Semih, Potential neoplastic effects of parathion-methyl on rat liver, J. Environ. Sci. 21 (2009) 696-699.

[57] D.L. Straus, D. Schlenk, J.E. Chambers, Hepatic microsomal desulfuration and dearylation of chlorpyrifos and parathion in fingerling channel catfish: Lack of effect from Aroclor 1254, Aquat. Toxicol. 50 (2000) 141-151.

[58] J. Senthilnathan, L. Philip, Photodegradation of methyl parathion and dichlorvos from drinking water with $\mathrm{N}$-doped $\mathrm{TiO} 2$ under solar radiation, Chem. Eng. J. 172 (2011) 678-688.

[59] L. Zheng, F. Pi, Y. Wang, H. Xu, Y. Zhang, X. Sun, Photocatalytic degradation of Acephate, Omethoate, and Methyl parathion by
Fe3O4@SiO2@mTiO2 nanomicrospheres, J. Hazard. Mater. 315 (2016) 11-22.

[60] B. Tiwari, S. Chakraborty, A. Kumar, A. Kumar, Biodegradation and rapid removal of methyl parathion by the paddy fi eld cyanobacterium Fischerella sp ., Algal Res. 25 (2017) 285-296.

[61] A. Bermúdez-Couso, D. Fernández-Calviño, M. Pateiro-Moure, J.C. Nóvoa-Muñoz, J. SimalGándara, M. Arias-Estévez, Adsorption and desorption kinetics of carbofuran in acid soils, J. Hazard. Mater. 190 (2011) 159-167.

[62] A.-A. Salarian, Z. Hami, N. Mirzaei, S.M. Mohseni, A. Asadi, H. Bahrami, M. Vosoughi, A. Alinejad, M.-R. Zare, N-doped TiO2 nanosheets for photocatalytic degradation and mineralization of diazinon under simulated solar irradiation: Optimization and modeling using a response surface methodology, J. Mol. Liq. 220 (2016) 183-191.

[63] S.R. Mirmasoomi, M. Mehdipour Ghazi, M. Galedari, Photocatalytic degradation of diazinon under visible light using $\mathrm{TiO} 2 / \mathrm{Fe} 2 \mathrm{O} 3$ nanocomposite synthesized by ultrasonicassisted impregnation method, Sep. Purif. Technol. 175 (2017) 418-427..

[64] M. Bavcon Kralj, U. Černigoj, M. Franko, P. Trebše, Comparison of photocatalysis and photolysis of malathion, isomalathion, malaoxon, and commercial malathionProducts and toxicity studies, Water Res. 41 (2007) 4504-4514. d

[65] M. Sun, D. Liu, Z. Dang, R. Li, Z. Zhou, P. Wang, Enantioselective behavior of malathion enantiomers in toxicity to beneficial organisms and their dissipation in vegetables and crops, J. Hazard. Mater. 237 (2012) 140-146.

[66] H. Yu, X. Wang, H. Sun, M. Huo, Photocatalytic degradation of malathion in aqueous solution using an $\mathrm{Au}-\mathrm{Pd}-\mathrm{TiO} 2$ nanotube film, J. Hazard. Mater. 184 (2010) 753-758.

[67] A.N. Kadam, R.S. Dhabbe, M.R. Kokate, Y.B. Gaikwad, K.M. Garadkar, Preparation of N doped $\mathrm{TiO} 2$ via microwave-assisted method and its photocatalytic activity for degradation of Malathion, Spectrochim. Acta Part A Mol. Biomol. Spectrosc. 133 (2014) 669-676.

[68] N.A. Ramos-Delgado, L. Hinojosa-Reyes, I.L. Guzman-Mar, M.A. Gracia-Pinilla, A. Hernández-Ramírez, Synthesis by sol-gel of $\mathrm{WO} 3 / \mathrm{TiO} 2$ for solar photocatalytic degradation of malathion pesticide, Catal. Today. 209 (2013) 35-40. [69] Y. Zhang, K. Pagilla, Treatment of malathion pesticide wastewater with nanofiltration and photo-Fenton oxidation, Desalination. 263 (2010) 36-44. 